\title{
INHIBITORS OF CORROSION INDUCED BY SULFATE-REDUCING BACTERIA
}

\author{
L.M. Purish, D.R. Abdulina, G.O. Iutynska \\ Zabolotny Institute of Microbiology and Virology, NAS of Ukraine, \\ 154 Acad. Zabolotny Str., Kyiv, 03143, Ukraine \\ e-mail:larisa.purish@gmail.com
}

Currently, a lot of researcher's attention is devoted to the problem of microbiologically influenced corrosion (MIC), since it causes huge damages to the economy, initiating the destruction of oil and gas pipelines and other underground constructions. To protect industrial materials from MIC effects an organic chemical inhibitors are massively used. However, the problem of their use is associated with toxicity, dangerous for the environment that caused the need for development the alternative methods of MIC repression. At the review, the data about different types of inhibitors-biocides usage has provided. The chemical inhibitors features are given and the mechanisms of their protective action are considered. The screening results and use of alternative and eco-friendly methods for managing the effect of corrosion caused by sulfate-reducing bacteria (SRB) are highlighted. Methods of joint application of chemical inhibitors and enhancers, such as chelators, biosurfactants, which contribute to reducing the concentration of chemical inhibitors, are discussed. The possibility of disruption of the quorum sensing interaction in the bacterial community to prevent the biofilm formation is considered. The information about the use of natural plant extracts, food waste, as well as by-products of agro-industrial production to combat MIC is provided. The development of biological corrosion control methods (to combat MIC) is of great importance for creating the best alternative and eco-friendly approaches to managing the effect of corrosion caused by SRB. The analysis of the literature data indicates the need to find the best alternatives and environmentally friendly solutions.

Keywords: microbial corrosion inhibitors, sulfate-reducing bacteria, biofilm, "green biocides".

Recently, it has been proved that microbiologically influenced corrosion (MIC) is a cause of $20 \%$ of all cases of corrosion of oil and gas pipelines, underground metal structures, industrial equipment and marine vessels [1-4]. According to researchers, MIC accounts for $30-40 \%$ of corrosion losses in the oil and gas industry, while the cost of replacing pipelines reaches 250 million $\$$ per year $[5,6]$. The direct costs of fighting MIC are billions of dollars, including millions of dollars spent on inhibitors-biocides [6]. Considered the mentioned above the development and improving the inhibitors used as well as searching the alternative, eco-friendly biocides is an actual problem.

The role of sulfate-reducing bacteria in biocorrosive processes. According to the modern concept, MIC is a bio electrochemical process occurring in a biofilm on the metal surface $[7,8]$. In MIC, sulfate-reducing bacteria (SRB), which are directly involved in the bio electrochemical process occurring on the metal surface play the leading role $[9,10]$. SRB are widespread in anaerobic zones with a sulfur and carbon compounds as well as in marine hypersaline environments [11, 12]. A significant amount of SRB habits in an anaerobic environment contaminated with gasoline, fuel oil or other petroleum products [13]. Individual SRB cells, capable of decomposing hydrocarbons, founded in crude oil $[14,15]$. SRB colonize oil pipelines, tank vessels or other industrial constructions that have suitable environmental conditions. In oil fields, hydrogen sulfide produced by SRB, the presence of which leads to a deterioration in the quality of oil and gas, making it difficult to process them. Difficulties caused by bacterial activity are observed during the exploitation of oil fields. Emergency spills of hydrocarbons and their mixtures into the environment and, consequently, its pollution are also occurred. The detection of SRB and increasing in their number is a clear signal of MIC, thus the monitoring of the corrosion processes development have focused on the detection of SRB.

Mechanisms of microbiologically influenced corrosion. MIC of iron and steels in the presence of SRB is a complex multi-stage electrochemical 
process initiated and catalyzed by bacteria. Bacteria are directly involved in that type corrosion, due to the metabolic reaction of dissimilatory sulfate reduction $\left(\mathrm{SO}_{4}{ }^{2-}+8 \mathrm{H}^{+} \rightarrow \mathrm{S}^{2-}+4 \mathrm{H}_{2} \mathrm{O}\right)$. Sulfate reducers play a key role in the process of cathode depolarization, using polarized hydrogen from the metal surface for an energy-generating sulfate reduction reaction, thus accelerating corrosion. In addition, they can stimulate corrosion due to the secondary effect of their metabolites $\left(\mathrm{H}_{2}\right.$, $\mathrm{S}^{0}, \mathrm{HS}^{-}, \mathrm{S}^{2-}$ ), which form on the metal surface a galvanic pair "iron sulphide-iron". The formation of sulphide films significantly increases the rate of corrosion and causes pitting formation [16, 17]. This mechanism of direct and indirect participation of SRB in the corrosion of carbon steels has been confirmed by our electrochemical studies. The introduction of Desulfovibrio sp.10 strain into the sterile Postgate " $\mathrm{B}$ " medium led to acceleration of the cathode and anode corrosion reactions on steel and shifted the stationary potential in the negative direction. This may indicate the direct participation of bacteria in the cathode reaction and the subsequent decrease in their catalytic activity [18].

SRB is a diverse group of bacteria with significantly different corrosion activity $[19,20]$. Other bacterial species that produce corrosive compounds can also be a factor in pitting corrosion. In particular, some bacterial species of Clostridium genus could stimulate MIC by producing organic acids and $\mathrm{H}_{2} \mathrm{~S}$ using sulfur or thiosulfate as electron acceptors [21-23].

The role of biofilm in microbiologically influenced corrosion. Studies of recent decades have shown that in natural ecosystems, most bacteria exist in the form of specifically organized biofilms attached to substrates [7, 8]. Biofilms are a highly organized, structured community of bacteria of one or more species [24, 25]. The microbial community functions in the biofilm as a coordinated consortium loaded in the exopolymer matrix (EPM) of extracellular metabolites synthesized by it [24, 26].

Biofilms are the optimal form of bacterial existence and represent an accumulation of cells and their metabolic products, among which exopolymers play an important role. In the composition of exopolymers proteins, exopolysaccharides, lipopolysaccharides and other compounds containing functional groups that can react with metal ions have been identified [27]. Because of this interaction, exopolymers integrate metal ions, which accelerates the corrosion process.
In this case, the biofilm acts as an anode on which the metal is destroyed [28]. Commonly SRB in a biofilm are developing in a microbial community, in which other bacteria persist, including heterotrophs, which can be aerobes, facultative or obligate anaerobes [29]. The corrosion aggressiveness of the microbial community has determined by the ability of the biofilm formed by it to catalyze destruction electrochemical processes on the metal surface $[27,29]$.

In the biofilm, bacteria can use various protective mechanisms, including diffusion restriction, decreasing the metabolic rate for reducing nutrient intake, formation of resistant cells, activation of resistance genes, etc. [30, 31]. Protective mechanisms reduce the susceptibility of bacteria to biocides. This is typical for metal pipelines, where corrosion deposits changes the spatial organization of the surface and create a barrier for the diffusion of biocide and biostatic inhibitors. The bacterial defense mechanism against biocide action is a factor of evolution and can develop a high level of bacterial resistance to biocides and inhibitors [32].

The use of chemical inhibitors to fight microbiologically influenced corrosion. The most promising and effective method of fighting MIC is the use of inhibitors and biocides. Currently, a large number of metal corrosion inhibitors have been created, but only a limited number of compounds usable in industry are known as MIC inhibitors. Since MIC inhibitors, in addition to the requirements characteristic of the chemical process, have a number of specific requirements related to the peculiarities of biological corrosion running. In particular, the metabolic activity of bacteria, the effects on the cathode and anode reactions of the corrosion process as well as possibility of the formation of a galvanic pair "iron sulphideiron" have been noticed. MIC inhibitors should have bactericidal properties, be eco-friendly and retain their protective properties for a long time. The spectrum of chemical inhibitors is currently very wide. The most common MIC inhibitors are heterocyclic organic compounds, containing atoms of oxygen, sulfur and nitrogen, also nitrogencontaining heterocyclic compounds and their combinations with metal salts, high molecular weight alcohols and aldehydes, amines and amides, sulfonium acid, fatty acid derivatives of thiourea, thiazole, quaternary nitrogen-containing compounds, phenols, aldehydes (formaldehyde), heavy metal salts, etc. [33-38]. Aldehydes (formaldehyde, glutaraldehyde), and amine (quaternary amines and cacodemon), halogenated 
(bronopol and 2-2-dibrom-3-nitrilopropionamide) and sulfur compounds, carbamate, metronidazole and quaternary phosphonium salts are used as inhibitors-biocides to fight SRB in the oil and gas industry [39-41].

We conducted comparative studies from estimating the efficacy of the spectrum of industrial inhibitors in the presence of Desulfovibrio sp. in the medium [42]. Benzoates, thiourea derivatives, amines and high molecular weight polyethylene alkyl esters, nitrogen-containing heterocyclic compounds and cationic nitrogen-containing surfactants were used. The study found that the most effective corrosion inhibitors of low-carbon steel in the presence of Desulfovibrio sp. 10 bacteria were cationic nitrogen-containing surfactants or their combinations with heavy metals salts and halide ions [42]. These compounds suppressed the corrosion of steel due to decreasing the activity of SRB. Adsorbed on the metal surface and forming a protective film, the inhibitors hold down the process of hydrogen release and, thus, reduced the catalytic activity of SRB as a depolarizers of the cathode process [43]. According to the researchers, the biological effect of quaternary ammonium cationically active surfactants consists in the destruction of the bacterial cell membranes structures and denaturation of cellular proteins, which improves the penetration of antimicrobial compounds [39, 41]. In the oil and gas industry, in addition to mentioned above compounds, imidazolines, acetylated alkandienes, oleates, butyrates, caproates, dimethylbenzenesulfonates, as well as compounds containing boron, stanum, mercury are used [44]. Also it is known about the use of synergistic compositions of inhibitors, such as glutaraldehyde with quaternary ammonium salts $[45,46]$.

Duncan K.E. [47] showed the effect of filmforming corrosion inhibitor chemistries with a hydrophobic tails from C8 to C20 on a sulfidogenic microbial community isolated from the biofilm from oil pipeline. For this aim, a model pipeline system has created using various inhibitors. Inhibitor A had a hydrophobic tail C12-C20, it contained nitrogen-containing surfactants, such as quaternary ammonium or imidazoline, which have a high toxicity. The less toxic inhibitor $\mathrm{B}$ with a short hydrophobic chain C8-C10 contained polyaminoacids or various sulfur and nitrogen compounds with or without small hydrophobic tails. In the model system, two flow cells received no chemical treatment ("controls"). An inhibitor A was introduced into two flow cells, and an inhibitor B was introduced into other two. From tank, the nutrient medium and bacterial inoculum continuously pumped through six flow cells containing mild steel samples. The samples were extracted after 1 month and the corrosion and composition of the biofilm microbial community were analyzed. There have revealed the changes in the composition of the dominant species in the biofilm. It has noted that SRB species (Desulfovibrio indonesiensis) prevailed in the initial inoculum, but during the experiment, its representation decreased, and previously secondary members of the community became dominant, which depended on the presence of a type of corrosion inhibitor A or B. These results suggest that certain SRB species are better competitors for attachment to metal surfaces (for example, Desulfovibrio alkalitolerans) and that corrosion inhibitors may affect SRB species differently, for example, more representatives of Desulfomicrobium are found in biofilms treated with an inhibitor A, which is considered more toxic. The total number of pitting with a diameter of $>10 \mathrm{~mm}$ and the maximum corrosion rate significantly correlated with each other and with the total amount of SRB Desulfomicrobium sp. The obtained results showed that the effect of corrosion inhibitors on the microbial community is complex and cannot be equated with a non-discriminatory destruction effect. The biomass in the flow cells treated with inhibitor A was in 10-20 times higher than for inhibitor B, contrary to the expected toxic effect. Both due to the chemical complexity of the inhibitors and microbial community in the flow cells, it was impossible to determine the direct roles of the various members of the microbial community. The maximum frequency of pitting corrosion has significantly correlated with the sum of bacteria amount of the Desulfomicrobium genus together with Clostridiales and the sum of bacteria amount of the Desulfomicrobium genus together with Betaproteobacteria. The absence of a reliable correlation with the number of Deltaproteobacteria suggests that not all these representatives contributed equally to $\mathrm{MIC}$ and that it is not enough to target one bacterial group during MIC monitoring. The obtained results confirmed previous observations that MIC is the result of a complex interaction of biological, chemical and physical factors [47].

Metabolic inhibitors. In addition to the abovementioned inhibitors-biocides, metabolic inhibitors are used to fight SRB and suppress the production of biogenic sulfide. A metabolic inhibitor is a compound that effectively repress the metabolic 
activity of SRB without direct destroying the bacteria after contact with the inhibitor. Metabolic inhibitors suppress the ability of SRB to produce ATP and, as a result, cells are unable to grow and/ or divide, which can ultimately cause their death. Commonly, nitrites, molybdates, tungstates, selenates and anthraquinones are used as metabolic inhibitors. As is known nitrite and molybdate inhibit the metabolism of SRB. Nitrite inhibits the enzymes of - dissimilatory sulfate reduction pathway, blocking the sulfate dissimilation of SRB. The enzyme ATP sulfurylase activates the sulfate from ATP to adenosine phosphosulfate. Due to application of molybdenum in this reaction, an unstable adenosine phosphomolybdate is formed, and hydrolyzes spontaneously to AMP and molybdenum, exhausting the reserves of ATP.

Positive results have been reported on the use of nitrite and/or molybdenum for the control of sulfate reduction and methanogenic activity in sewage systems, pig manure treatment systems and anaerobic digesters [48-50]. The inhibitory effect of nitrite on sulfate reduction and methane formation in sewage systems has studied in laboratory and in situ conditions. It has showed that inhibition by nitrite depends on both the concentration and the time of exposure, and stronger inhibition has observed at higher concentrations of nitrite and/or longer exposure time [51]. The addition of nitrite for 3 weeks led to a significant ( $>90 \%$ ) decrease in the number and activity of sulfate-reducing and methanogenic bacteria in biofilms obtained from the surface of sewer systems [52].

To control the formation of sulphides and methane, formaldehyde and molybdate are also periodically added to the sewer systems. Formaldehyde at a concentration of $12-19 \mathrm{mg} / \mathrm{L}$ was able to suppress the formation of sulphides in wastewater [53]. Although biocides such as formaldehyde and molybdate inhibit SRB, their potential negative residual environmental effects impair their widespread use. For comparison, nitrite can be easily utilized by heterotrophic bacteria in sewer networks and/or sewage treatment plants and, therefore, does not pose a serious problem for the environment. In addition, it has shown that certain doses of nitrite stimulate the development of nitrite-reducing sulfide-oxidizing bacteria that are able to oxidize residual sulfide with nitrite. This means that nitrite acts as a metabolic inhibitor and as sulfide oxidizer.

In oil and gas fields, in order to reduce the concentration of a chemical biocide, a combination of a biocide and a metabolic inhibitor also used.
The biogenic sulphide production by SRB inhibition occurs due to the synergistic action of the biocide component and the metabolic inhibitor. The composition of synergistic combinations includes the metabolic inhibitors nitrite and molybdate and the biocides glutaraldehyde, brochopol, formaldehyde, benzalkonium chloride (quaternary amonium cationic active surfactant), quaternary phosphonium (TPHS) [54]. The efficacy of different biocides and metabolic inhibitors (nitrites and molybdates) mixtures has studied on the SRB microbial consortium isolated from process water obtained from the Colleville oil field in Saskatchewan, Canada. In the consortium mainly identified bacteria of the Desulfovibrio genus. It has found that glutaraldehyde, benzalkonium chloride and bronopol showed synergism with metabolic inhibitors in most combinations. The significant synergy has observed between mentioned above biocides and nitrite. The specific action of nitrite as an inhibitor of dissimilatory sulfite reductase can be combine with a wide range of biocides to achieve synergy. Molybdenum was less effective than nitrite in combination with biocides. It is known that nitrite reduces to nitrogen or ammonia, which do not cause great environmental harm. Since molybdenum forms more toxic products than nitrite, the use of a synergistic combination of "nitrite-biocide" to suppress sulfate reduction is more favorable from a practical point of view for use in oil and gas reservoirs, where it is necessary to control the formation of sulfides [54].

Since the 1990s, nitrate has been used in oil tank systems to combat SRB in oil fields for biological purification [55-58]. Nitrate has a direct and indirect effect on the recovery of sulfate and controls the reduction of sulfate in several ways: a) as one of the most thermodynamically favorable electron acceptors; nitrate reduction is much more preferred than sulfate, leads to competitive exception of organisms, which reducing sulfate, unless they compete for the same electron donor; b) in a case of incomplete reduction of nitrate can be formed intermediate nitrite, which is very toxic to sulphate-reducing bacteria; c) the reduction of nitrate associated with the oxidation of sulfides, may form elemental sulfur or sulfate, depending on bacterial strain $[59,60]$.

Also perchlorates are used as a specific inhibitor to combat SRB [61-63]. Perchlorate is effective at lower concentrations compared to nitrate as an inhibitor of sulfate reduction. It acts as a direct inhibitor of some sulfate reduction pathway enzymes, and an indirect inhibitor being 
a more energetically advantageous reducing agent of sulfate compared to nitrate [64]. Taking into account the inhibitory properties of nitrates and perchlorates, the efficacy of their combined action has studied. The efficacy of mixed treatment with nitrates and perchlorates has studied on a pure culture of Desulfovibrio alaskensis G20 under periodic cultivation conditions [63]. The study showed that the inhibition is additive, but tends to antagonize, demonstrating that two compounds have similar mechanisms of action. Subsequent biochemical and molecular studies confirmed that the common target of the inhibitors was the ATPsulfurylase enzyme, an necessary for the reduction of sulfate and present in all SRBs. Moreover, perchlorate is synergistic with nitrite, and nitrate with chlorite, which suggests that intermediates of the metabolism of individual pathways can mediate the synergistic effect of combined inhibition. The efficacy of the combined action of nitrate and perchlorate has also studied in a dynamic system using a microbial community isolated from an oil field [65]. For evaluation of the possible synergy from the treatment both with nitrate and perchlorate, glass columns filled with sulfide biogenesis soured marine sediment and pre-soured marine sediments were washed with a medium containing sulfate and treated with inhibitors: (a) perchlorate; (b) nitrate; (c) perchlorate and nitrate; or (-) without an inhibitor. Changes in the microbial community were tracked along the length of the columns during six stages of increasing the treatment concentration. At final stage, all the processing has deleted. The results showed that the combination of perchlorate and nitrate in equimolar ratios is an effective strategy for sulfidogenesis inhibiting, which is more effective than treatment with nitrates only. The analysis of the microbial community structure showed that the combined inhibitors act similarly to the independent treatment with perchlorate, and without nitrate treatment. With mixed treatment, a microbial community is formed, similar to that of perchlorate treatment. This confirms the idea that perchlorate is the main active ingredient that causes inhibition in the columns during mixed treatment. Perchlorate has some important distinguishing effects on the community that are not reveal when treated with only nitrates. All known dissimilatory bacteria that reduce perchlorates have the ability to oxidize sulfide to elemental sulfur $[62,66]$. Elemental sulfur concentrations were higher in columns containing perchlorate, which confirms the results of previous studies, that the reduction of perchlorate is associated with the bio oxidation of sulfides $[62,66]$. Since sulfide is an electron donor in this reaction, the final sulfur concentration will directly depend on the residual sulfide concentration after suppressed SRB's activity. Representatives of the genus Desulfotignum, one of the most common sulfate reducers in this community, have inhibited only in columns treated with perchlorate. The presented results show that single perchlorate or a mixture of perchlorate plus nitrate is more effective for fighting with biogenic sulfide souring in oil fields than one nitrate. In addition, when perchlorate had added, changes occur in the microbial community led to reduction of sulfates, hence the suppression of the formation of hydrogen sulfide and sulphides in oil fields.

Alternative approaches to fight microbiologically influenced corrosion. Traditional chemical inhibitors-biocides, such as amines, amides and salts of quaternary compounds are quite toxic; in addition, most of these substances do not have the required level of biodegradability and are harmful to the environment. Last years, alternative methods have developed to reduce the negative impact of inhibitors and biocides on environment. The search for new substances based on natural compounds with antimicrobial properties is relevant.

The use of biocide enhancers. One of the ways to reduce the dosage of chemical biocides and reduce their harmful effect on the environment is the use of substances with enhancing effect. Biocide enhancers do not necessarily have to possess biostatic or biocide properties. If the substance contributes to the disintegration of biofilm cells and their transformation into planktonic ones, it has used as an enhancer of chemical biocides. Various substances are known that can be used as enhancers of chemical biocides.

Chelators are complexing agents that bind metal ions presented in water-soluble ingredients. Chelators can increase the permeability of the outer membrane of gram-negative bacteria cell walls, in particular SRB, since they can chelate $\mathrm{Mg}^{2+}$ and $\mathrm{Ca}^{2+}$ ions, as well as denature proteins, weakening the membrane. This makes the cell more susceptible to the attack of biocides and, consequently, increases their efficacy [67]. The use of chelators as biocide enhancers for resistant industrial biofilms controlling was patented by Raad et al. [68, 69] and was studied by other researchers $[70,71]$. The most common chelators used as biocide enhancers to combat $\mathrm{SRB}$ are ethylenediamindisuccinate (EDDS), ethylenediaminetetraacetic acid (EDTA) [69]. In experimental studies, the effects of biocide enhancers for the suppression of planktonic and 
biofilm cells of the corrosive-relevant SRBs Desulfovibrio vulgaris ATCC 7757 were studied. A triple biocide mixture consisting of glutaraldehyde biocides tetrakis hydroxymethyl-phosphonium sulfate (THPS) and chelators - EDDS, and methanol was used in the work. This cocktail has showed the significant effectiveness in suppressing SRB. In particular, glutaraldehyde enhanced with methanol and EDDS completely removed the biofilm on carbon steel samples in a modified medium [72].

The use of D-amino acids as biocide enhancers [73]. Also suggested that some D-amino acids modify the synthesis of peptidoglycan molecules present in the walls of all bacterial cells [74]. D-amino acids can to disperse the biofilm by disrupting protein synthesis [75]. In a study by $\mathrm{Xu}$ et al. [76], D-amino acids has used to treat a biofilm formed on steel samples by Desulfovibrio vulgaris bacteria isolated from oil fields. Since D-amino acids slightly inactivated biofilm cells, the authors suggested that biocidal stress is necessary to combat resistant industrial biofilms. For this purpose, the combined use of a THPS inhibitor and D-amino acids (D-tyr, D-met, D-leu and D-trp) (has) have used, which significantly reduced the formation of SRB biofilms that cause corrosion on carbon steel surface. In addition, it was investigated the suppressing efficacy of pure culture $D$. vulgaris and biofilm microbial community with THPS biocides and alkyldimethylbenzyl ammonium chloride together with D-amino acids. Significant synergistic effect has observed when using THPS and D-amino acid (D-tyr). However, the suppression of pure culture $D$. vulgaris was more effective than the suppression of the microbial community in the biofilm [76]. The use of D-amino acids as a biocide enhancer is promising in the fight against MIC.

The use of bacteriophages to fight microbiologically influenced corrosion. Bacteriophages have used to prevent biofouling in wastewater treatment systems [77]. Studies have shown that the bacteriophage can remove biofilm from membrane filters. However, the use of bacteriophages in industry is problematic due to the extreme specificity of their hosts. Phages affecting D. vulgaris or D. aespoeensis, may not infect other Desulfovibrio species [78, 79]. Therefore, a cocktail of phages will be required for the SRB industrial biofilm community. However, the largescale use of phage mixtures is cost consuming. Since some specific phages can infect persistent cells in biofilms it is suggested that phages can be combined with biocides and their enhancers. Additional researches still are needed for the industrial use of phages.

The use of biosurfactants. Their use can be effective environmentally friendly alternative solution to replace traditional chemical biocides. Biosurfactants are secondary metabolites, surfaceactive amphiphilic compounds synthesized by certain bacteria, fungi and yeasts. Biosurfactants are environmentally safe due to their low toxicity and high biodegradability. The producers of some known biosurfactants are Pseudomonas aeruginosa - rhamnolipids, Bacillus subtilis surfactin, yeast of Candida genus - sophorolipids, Acinetobacter calcoaceticus - emulsifier [80, 81]. Biosurfactants have anti-adhesive, antimicrobial and biofilm-destroying properties. Bacterial surfactants, directly interacting with the matrix components, change the physical properties of the biofilm surface and induce its degradation. Bacteria of Bacillus genus are well-known producers of biosurfactants. In addition to the synthesis of a wide range of antimicrobial compounds (polymyxin B, gramicidin $\mathrm{S}$ ), they produce surfactant lipopeptides, i.e. rhamnolipids, glycolipids. Some species of Bacillus genus (natural or genetically modified) can produce antimicrobial compounds in the biofilm that inhibit the development of SRB, led to decreasing of steel corrosion rate [82]. It has been shown that the supernatants of gramicidin $S$ producers inhibit the SRB growth [83]. Biosurfactant produced by Bacillus licheniformis after addition to the medium at a concentration of $1 \%$ completely killed SRB in 3 hours. Studies by Purwasena et al. [84] showed that the biosurfactant produced by native bacteria Bacillus sp. isolated from an oil reservoir has anticorrosive properties. Based on this compound, a new antimicrobial preparation is developing, designed to fight biofilm-forming bacteria. The minimum inhibitory concentration of the preparation was determined to suppress the biofilm microbial community and reduce the corrosion rate of carbon steel [84]. It was studied a glycolipid produced by Pseudomonas stutzeri F01 as an environmentally friendly microbial inhibitor (biocide) of carbon steel corrosion (API 5LX), which is widely used in the oil and gas industry. The authors have shown that this biosurfactant has antibacterial properties against corrosive SRB species, manganeseoxidizing or iron-oxidizing bacteria [85]. It was noticed the decreasing of stainless steel corrosion in the presence of surfactants produced by Pseudomonas fluorescens [86]. Among the bacteria isolated 
from the oil reservoir, producers of glycolipids and rhamnolipids had identified. The screening of biosurfactants that potentially have been used as an alternative biocide for biofilms associated with biocorrosion in the oil and gas industry was carried out. The studied biosurfactants may be promising for use in the oil industry not only to increase oil output, but also as alternative biocides [87].

Quorum Quenchers for inhibition of Quorum Sensing in biofilms. Main MIC processes occur in a biofilm, the formation of which is regulated by quorum sensing (QS) mechanism for transmitting chemical signals used by huge amount of bacteria [88]. QS is the gene expression regulation in response to fluctuations in cell density in a biofilm. Bacteria synthesize and release into the environment chemical signaling molecules called auto-inductors [89]. Different bacteria use various signaling molecules for QS. Typically, as signaling molecules Gram-negative bacteria use N-acyl-homoserine lactone (AHL), while Gram-positive bacteria use peptides [90]. Despite the huge amount of knowledge devoted to QS in the model bacteria Vibrio harvey and $V$. fischeri species, this mechanism is still little-known for SRB. In particular, the presence of QS in SRB has proved in the works [91]. To identify quickly the activity of QS in bacteria, the authors developed an analysis based on the expression of $\beta$-galactosidase enzyme. The result showed that several AHLs (C6-AHL, oxo-C6-AHL, C8-AHL, C10 AHL and C12-AHL) have produced by $D$. vulgaris and other Desulfovibrio species [91]. Various AHLs have founded in the biofilm of microbial mats containing a large amount of SRB [92]. As an alternative approach to reduce corrosion losses, the possibility of regulating the formation of a biofilm by influencing QS is considered. A new method based on Quorum Quenchers (QQ), which blocks the ability of bacteria to communicate in a biofilm, is proposed. The approach of QQ as a method of MIC suppression based on suggestion that interference with bacterial communication QS-channels, will limit the formation of biofilm and the resulting SRB metabolic activity. The use of QQ reduced the biofouling of membranes and suppressed the virulence factors of some pathogens [93]. In recent years, there has been evidence that QQ can be achieve due to enzymes that interfere with the transmission of bacterial signals in the biofilm. Highly-stable SsoPox enzyme (quorum suppressing lactonase) has been developed, which interferes with the transmission of bacterial signals [94]. It has been shown that by disrupting QS lactonases are able to inhibit bacterial virulence and the formation of bacterial biofilm $[95,96]$. To estimate the effect of biological and enzymatic additives in QQ for reducing steel corrosion, a comparative study of their anticorrosive activity has conducted. Various chemical (magnesium peroxide), biological (surfactin, capsaicin and gramicidin) and extremely stable non-biocidal enzyme lactonase have used. Under laboratory conditions, experimental steel samples were puted in water picked from the Upper Harbor of Duluth, Minnesota where significant corrosion of the steel constructions has noted. Biocorrosion has measured after 8 weeks by counting the number and degree of pitting on the samples, as well as using an ESEM images of their surface. All three experimental additives significantly reduced the formation of pitting on steel samples: surfactin, magnesium peroxide and quorum-quenching lactonase by $31 \%, 36 \%$ and $50 \%$, respectively. Therefore, the addition of lactonase most reduced corrosion. The sequencing of the V4 region of the 16S rRNA gene in the total microbial DNA showed that decrease in corrosion was associated with significant changes in the composition of bacterial communities on steel surfaces. These results demonstrate the potential of highly stable quorum-quenching lactonases to provide a reliable method of processing steel structures and prevent biocorrosion [97]. However, the large-scale use of QQ for SRB inhibition has not yet been used, since there is insufficient data on the presence of QS in SRB.

Use of natural resources, plant extracts and food industry waste to fight sulfate-reducing bacteria. Connected by problem of environmental pollution, many works recently has been devoted to the study of a new type of biocides, the so-called "green inhibitors". The term "green inhibitors" is highly effective, eco-friendly substances of organic origin obtained from natural resources, plant extracts and from food industry wastes. Despite chemical ones, "green inhibitors" have characterized by biodegradability, renewability and environmental safety [98]. These include, for example, plant extracts widely distributed in nature, in addition, by-products of agro-industry and agricultural waste are used [99]. For example, cow urine in a much lower concentration compared to its chemical analogues was able to kill living SRB [100].

Questions about the use of plant extracts and food industry wastes to fight the activity of bacteria, including SRB, have been considered 
in numerous works [101-103]. Zain et al. [99] tested 8 natural biocides on SRB culture for their antibacterial activity. Extracts of various plants were used such as Allium sativum (garlic), Zingiber officinale (ginger), Curcuma longa (turmeric), Piper beetle (betel leaves), Capsicum pepper (chili), oak galls (manjakani), Clinacanthus nutans (belalai gajah) and Camellia sinensis (green tea). For this purpose, $10 \mathrm{~g}$ of a powdered sample of dried plant parts was extracted with $50 \%$ methanol (green tea, turmeric, betel leaves and garlic), $100 \%$ methanol (cloves, chili, manjakani and ginger) and distilled water (belalai gajah leaves). Then under reduced pressure, methanol was evaporated to yield darkbrown syrup, and between $\mathrm{CHCl}_{3}$ and water, the syrup was partitioned. Then, using $3 \% \mathrm{HCl}$, the $\mathrm{CHCl}_{3}$ partition was extracted and the $\mathrm{CHCl}_{3}$ solution was evaporated to obtain the green viscous residue. Dried extracts were added to Postgate " $\mathrm{B}$ " media in final concentration $5 \%$. The studied herbs differed in their effect on the SRB growth. Some extracts even enhanced the growth of planktonic SRBs, and some stimulated the formation of biofilms. Extracts from the green tea, belalai gajah and turmeric leaves turned out to be the most promising, since they not only prevented the formation of biofilm, but also decreased the overall growth of SRB. After adding $5 \mathrm{~mL}$ of these extracts to $100 \mathrm{~mL}$ of bacterial culture, the number of planktonic cells decreased by more than $50 \%$, which can subsequently lead to a decrease in corrosion losses. The antimicrobial effect of the tested plant extracts is most likely due to the presence of such compounds as flavonols, phenolic acid, terpenes, anthocyanins, stilbens and tannins [99]. Neem extract also showed antimicrobial properties and reduced the corrosion aggressiveness of SRB by $50 \%$. Other natural plant extracts also showed a significant effect on the activity of SRB, although they did not completely suppress bacterial growth [6].

Many works are devoted to the study of the possibility of using biowastes as MIC inhibitors. By-products of the food industry and solid wastes that are usually disposed of or used for animal feed can serve as a cheap source of biologically active biocidal compounds [104]. Pectin extracted from citrus peel has used as an environmentally friendly corrosion inhibitor of mild steel [105]. Watermelon rind, seeds and by-products obtained from tomatoes were also used [106]. Moreover, the possibility of using fresh plant leaves from bananas, sugar cane and watermelons has investigated [107]. Among a large number of eco-friendly biocides, the seeds of Phoenix clactylifera have been used to prevent corrosion. The fruit of this berry is edible and very useful, and the seed, discarded as waste has studied for inhibition of steel corrosion. The inhibition efficacy was approximately $97 \%$ at $50^{\circ} \mathrm{C}$ [108].

Extracts of the peel of fruits such as mango, cashew, passion fruit and orange, as well as seeds and by-products of fruit juices production have studied as inhibitors of steel corrosion in an acidic environment [109]. The use of these bioactive residues provided an efficient, low-cost and environmentally safe platform for the production of useful compounds. Extracts from leaves, bark, seeds, fruits and roots consist of mixtures of compounds containing heteroatoms, often acted as effective inhibitors of metal corrosion in various aggressive environments. In addition to their eco-friendly properties, many plant extracts are inexpensive, easily accessible and renewable sources of substances of promising industrial significance. These characteristics are justified by the abundance of plant extracts components common with molecular and electronic structures of casual organic corrosion inhibitors, which provides them the ability to adsorb on metal surfaces [98, 99].

Conclusions. Organic chemicals that act as corrosion inhibitors developed for the oil industry back in the 1950s. However, the main problem of their use directly related to the toxicity impact for the environment, including for human health. The ideal and easiest way to reduce the harmful effects of chemical compounds is to replace them with less toxic alternatives. One of such methods is the addition of enhancers to chemical inhibitors, such as chelators, biosurfactants, D-amino acids, and other substances that help reduce the concentration of chemical inhibitors. The possibility of disruption of the QS interaction in the bacterial community, which helps to prevent the formation of biofilms on abiotic surfaces, is also considered. There is an increasing interest in the use of natural plant extracts, food waste, as well as by-products of agroindustry as inhibitors-biocides to prevent corrosion. The presence of certain chemicals in "green biocides", which can either damage the cellular structure of SRB, or interfere with the perception of quorum and limit intercellular communication, gives a new understanding of the prospects for using eco-friendly "green inhibitorsbiocides". However, additional research needed to elucidate the direct mechanism of action of these inhibitors and their effect on the metabolic 
activity of SRB and, consequently, the reduction of corrosion. The use of biological methods to fight SRB is of great importance for creating a better alternative and eco-friendly way to manage the effect of corrosion caused by SRB. The search for the best alternatives and environmentally friendly solutions is now an urgent problem. Despite the existence of numerous studies on the production of "green inhibitors-biocides" of a new type, researchers are still far from achieving the main goals for the production of eco-friendly inhibitors.

\section{ІНГІБІТОРИ КОРОЗІЇ, ІНДУКОВАНОЇ СУЛЬФАТ ВІДНОВЛЮВАЛЬНИМИ БАКТЕРІЯМИ}

\section{Л.М. Пуріш, Д.Р. Абдуліна, Г.О. Іутинська}

Інститут мікробіології і вірусологї ім. Д.К. Заболотного НАН України, вул. Академіка Заболотного, 154, Київ, 03143, Україна

\section{$\mathrm{Pезюме}$}

В теперішній час велика увага дослідників присвячена проблемі мікробно індукованої корозії, оскільки вона наносить значні збитки в економіці, ініціюючи руйнування нафто- і газопроводів та інших підземних комунікацій. Для захисту промислових матеріалів від впливу мікробно індукованої корозії масово використовують органічні хімічні інгібітори. Однак проблема їх використання пов'язана з токсичністю, небезпечною для оточуючого середовища, що обумовило необхідність розробки альтернативних методів боротьби 3 мікробно індукованою корозією. В огляді наведено дані про використання різних видів інгібіторів-біоцидів. Наведено характеристику хімічних інгібіторів і розглянуто механізми їх захисної дії. Приведені власні порівняльні дослідження ефективності ряду промислових інгібіторів. Показано, що за наявності Desulfovibrio sp. найбільш ефективними інгібіторами корозії маловуглецевої сталі $€$ катіоноактивні азотовмісні поверхнево-активні речовини. Розглянуто приклади використання для боротьби з сульфатвідновлювальними бактеріями метаболічних інгібіторів, а саме - нітриту та молібдату, що інгібують метаболізм бактерій. Висвітлено результати пошуку та використання альтернативних і екологічно безпечних методів захисту від корозії, що викликана сульфатвідновлювальними бактеріями. Обговорено методи сумісного використання хімічних інгібіторів та посилювачів, таких як хелатори, біосурфактанти та D-амінокислоти, які сприяють зниженню концентрації хімічних інгібіторів. Розглянуто можливість порушення кворум-сенсорних взаємодій у бактеріальному угрупованні для попередження формування біоплівки. Наведено відомості про використання для боротьби з мікробною корозією натуральних екстрактів рослин, а також відходів продукції агропромислового виробництва та побічних продуктів харчової промисловості, які, зазвичай, використовуються як корми для тварин або викидаються. Як екологічно чистий інгібітор корозії сталі запропоновано використовувати екстракти шкірки фруктів, таких як манго, банани, маракуя, апельсин, а також побічні продукти переробки томатів та фруктових соків. Окрім цього, висвітлено експериментальні дослідження з можливості використання свіжого листя цукрового буряку. Наведено приклади використання для запобігання утворення біоплівки та зниження активності сульфатвідновлювальних бактерій екстрактів різноманітних трав'янистих рослин, зокрема, доведена перспективність використання екстрактів листя зеленого чаю та куркуми. Показано, що екстракти $з$ листя, кори, плодів та коріння складаються з суміші сполук, що містять гетероатоми, які можуть бути ефективними інгібіторами корозії металів. Висунуто також припущення, що антимікробний ефект протестованих екстрактів рослин пов'язаний з наявністю в них таких речовин, як флавоноли, фенольна кислота, терпени, антоціани, стильбени та танін. Показано, що фітохімічні компоненти в екстрактах рослин мають багато спільного 3 молекулярними та електронними структурами органічних інгібіторів корозії, що забезпечує здатність адсорбуватися на металевих поверхнях та сприяти в боротьбі з мікробною корозією. Розробка біологічних способів боротьби з мікробною корозією має велике значення для створення альтернативних та екологічно безпечних підходів до керування ефектом корозії, що обумовлена сульфатвідновлювальними бактеріями. Аналіз даних літератури свідчить про необхідність пошуку кращих альтернатив і екологічно безпечних рішень.

Ключові слова: інгібітори мікробної корозії, сульфатвідновлювальні бактерії, «зелені» біоциди. 
1. Li X, Liu ZY, Zhang D, Du C. Materials science: share corrosion data. Nature. 2015; 527:441-442.

2. Larsen KR. A closer look at microbiologically influenced corrosion. Materials performance roundtable Q \& A. NACE International. 2014; 53:32-40.

3. Little BJ, Lee JS. Microbiologically influenced corrosion. Kirk-Othmer Encyclopedia of Chemical Technology. Wiley: New York; 2009.

4. Koch GH, Brongers MPH, Thompson NG, Virmani YP, Payer JH. Corrosion cost and preventive strategies in the United States, NACE International. 2002.

5. Kip N, van Veen JA. The dual role of microbes in corrosion. ISME J. 2015; 9(3):542-551.

6. Bhola SM, Alabbas FM, Bhola R, et al., Neem extract as an inhibitor for biocorrosion influenced by sulfate reducing bacteria: A preliminary investigation. Engineering Failure Analysis. 2014; 36:92-103.

7. Costerton IW, Lewandowski Z, Caldwell DE, et al. Microbial biofilms. Annual Rev Microbiol. 1995; 49:711-745.

8. Lewandowski Z. Structure and function of bacterial biofilms. Biofilms: Recent advances in their study and control. Evans LV, editor. Haywood Acad. Pub; 2000.

9. Hamilton WA. Sulphate-reducing bacteria and anaerobic corrosion. Annual Rev Microbiol. 1985; 39:195-217.

10. Lee W, Lewandowski Z, Nielsen PH, Hamilton WA. Role of sulfate-reducing bacteria in corrosion of mild steel: a review. Biofouling. 1995; 8:165-194.

11. Minz D, Flax JL, Green SJ, Muyzer G, Cohen Y, Wagner M, Rittmann BE, Stahl DA. Diversity of sulfate-reducing bacteria in oxic and anoxic regions of a microbial mat characterized by comparative analysis of dissimilatory sulfite reductase genes. Appl Environ Microbiol. 1999; 65:4666-4671.

12. Muyzer G, Stams AJM. The ecology and biotechnology of sulphate-reducing bacteria. Nat Rev Microbiol. 2008; 6:441-454.

13. Shi Y, Zwokinski MD, Schreiber ME, Bahr JM, Sewell GW, Hickey WJ. Molecular analysis of microbial community structures in pristine and contaminated aquifers: field and laboratory microcosm experiments. Appl Environ Microbiol 1999; 65:2143-2150.

14. So CM, Young LY. Isolation and characterization of a sulfate-reducing bacterium that anaerobically degrades alkanes. Appl Environ Microbiol. 1999; 65:2969-2976.

15. Davidova IA, Duncan KE, Choi OK, Suflita JM. Desulfoglaeba alkanexedens gen. nov., sp. nov., an n-alkane degrading sulfate reducing bacterium. Int J Syst Evol Microbiol. 2006; 56:27372742.

16. Iverson WP. Mechanism of anaerobic corrosion of steel by sulfate-reducing bacteria. Mater Perform. 1984; 23(3):28-30.

17. Xua C, Zhanga Y, Chenga G, Zhu W. Pitting corrosion behavior of $316 \mathrm{~L}$ stainless steel in the media of sulphate-reducing and iron-oxidizing bacteria. Materials Characterization. 2008; 59: 245-255.

18. Pogrebova IS, Kozlova IA, Purish LM, Gerasika SE, Tuovinen $\mathrm{OH}$. Mechanism of inhibition of corrosion of steel in the presence of sulfatereducing bacteria. Materials Science. 2001; 37(5):754-761.

19. Beech IB, Sunner JA, Hiraoka K. Microbe-surface interac- tions in biofouling and biocorrosion processes. Int Microbiol. 2005; 8:157-168.

20. Nemati M, Jenneman GE, Voordouw G. Impact of nitrate mediated microbial control of souring in oil reservoirs on the extent of corrosion. Biotechnol Prog. 2001; 17:852-859.

21. Mechichi T, Fardeau ML, Labat M, Garcia JL, Verhé F, Patel BKC. Clostridium peptidivorans sp. nov., a peptide-fermenting bacterium from an olive mill wastewater treatment digester. Int J Syst Evol Microbiol. 2000; 50:1259-1264.

22. Hernández-Eugenio G, Fardeau ML, Cayol JL, Patel BKC, Thomas P, Macarie H, Garcia J-L, Ollivier B. Clostridium thiosulfatireducens sp. nov., a proteolytic, thiosulfate- and sulfur-reducing bacterium isolated from an upflow anaerobic sludge blanket (UASB) reactor. Int J Syst Evol Microbiol. 2002; 52:1461-1468.

23. Sallam A, Steinbüchel A. Clostridium sulfidigenes sp. nov., a mesophilic, proteolytic, thiosulfate- and sulfur-reducing bacteri- um isolated 
from pond sediment. Int J Syst Evol Microbiol. 2009; 59:1661-1665.

24. Davey ME, O'Toole GA. Microbial biofilms: from ecology to molecular genetics. Microbiol Mol Biol Rev. 2000; 64(4):847-867.

25. Watnick P, Kolter R. Biofilm, city of microbes. J Bacteriol. 2000; 182(10):2675-2679.

26. Sutherland IW. Biofilm exopolysaccharides: a strong and sticky framework. Microbiology. 2001; 147:3-9.

27. Lewandowski Z, Dickinson W, Lee W. Electrochemical interactions of biofilms with metal surfaces. Wat Sci Tech. 1997; 36(1):295-302.

28. Beech I, Zinkevich V, Tapper R, Gubner R, Avci R. Study of interaction of sulphate-reducing bacteria exopolymers with iron using X-ray photoelectron spectroscopy and time-of-flight secondary ionization mass spectrometry. J Microbiol Methods. 1999; 36(1-2):3-10.

29. Hamilton WA. Microbially influenced corrosion as a model system for the study of metal microbe interactions: a unifying electron transfer hypothesis. Biofouling. 2003; 19(1):65-76.

30. Lewis K. Riddle of biofilm resistance. Antimicrobial Agents and Chemotherapy. 2001; 45(4):999-1007.

31. Campanac C, Pineau L, Payard A, et al. Interactions between biocide cationic agents and bacteria biofilms. Antimicrobial Agents and Chemo Therapy. 2002; 46(5):1469-1474.

32. McDouglad D, Rice SA, Barraud N, Steinberg PD, Kjelleberg S. Should we stay or should we go: mechanisms and ecological consequences for biofilm dispersal. Nat Rev Microbiol. 2012; 10:39-50.

33. Agaev NM. [Zakonomernosti sozdaniya biocidov, predotvrashchayushchih razvitie sulfatreduciruyshchih bakteriy i obrozovanie biogennogo serovodoroda]. Phiziko-chimicha mechanica materialiv. Materials Science (Special issue). 2000; 2(3):572-576. Russian.

34. Golyak YuV, Beloglazov SM. Inhibitor and bactericidal actions of substituted phenols upon corrosion of aluminum under the action of sulfate-reducing bacteria. Praktika protivokorrosionnoy zaschity. 2001; 1(19):11-16.

35. Diehl KH. Future aspects of biocide use. Polim
Paint Colour J. 1992; 182(4311):402404-405411.

36. Kelland MA. Production chemicals for the oil and gas industry. CRC Press: Boca Raton; 2009.

37. Kurmakova I, Bondar O, Polevichenko S, Demchenko N. Quaternary pyridinium salts as inhibitors of mild steel biocorrosion. Chemistry \& Chemical Technology. 2017; 11(3):314-318.

38. Kermani MB, Morshed A. Carbon dioxide corrosion in oil and gas production- a compendium. Corrosion. 2003; 59(8):659-683.

39. Boivin J. Oil biocides. Mater Perform. 1995; 34:65-683.

40. Cheung CWS, Beech IB. The use of biocides to control sulfate-reducing bacteria in biofilms on mild steel surfaces. Biofouling. 1996; 9:231-240.

41. Maillard UY. Bacterial target sites for biocide action. J Appl Microbiol Symp Suppl. 2002; 92:16S-27S.

42. Purish LM, Kozlova IA, Pogrebova IS. [Protect effectiveness of steel corrosion inhibitors in the presence of sulfate-reducing bacteria]. Praktika protivokorrosionnoy zaschity. 2013; 67(1):1824. Russian.

43. Pogrebova IS, Purish LM, Kozlova IA Tuovinen $\mathrm{OH}$. [Elektrokhimicheskye aspekty inhibirovaniya processa mikrobnoy korrosii slaty $\mathrm{v}$ prisutstvii sulfatreduciryuschih bacteriy]. Voprosy Khimii i Khimicheskoi Tekhnologii. 1999; 1:268-270. Russian.

44. Vigdorovich VI, Strelnikova KO, Nazina TN. [Bactericidal characteristics of amdor ic-7 and amdor ic-10 inhibitors of hydrogen sulfide and carbon dioxide corrosion of steel]. Kondensirovannye sredy i mezhfaznye granitsy. Condensed Matter and Interphases. 2012; 14(3):306-309. Russian.

45. Grab LA, Treis. AB. Comparartive biocidal efficacy vs sulfate-reducing bacteria. In Corrosion/92. NACE International: Houston, TX; 1992.

46. Gardner LR, Stewart PS. Action of glutaraldehyde and nitrite against sulfate-reducing bacterial biofilms. Journal of Industrial Microbiology and Biotechnology. 2002; 29(6):354-360.

47. Duncan KE, Perez-Ibarra BM, Jenneman G, Busch Harris J, Webb R, Sublette K. The effect of corrosion inhibitors on microbial communi- 
ties associated with corrosion in a model flow cell system. Appl Microbiol Biotechnol. 2013; 98(2):10.1007/s00253-013-4906-x.

48. Nemati M, Mazutinec TJ, Jenneman GE, Voordouw G. Control of biogenic $\mathrm{H}_{2} \mathrm{~S}$ production with nitrite and molybdate. Journal of Industrial Microbiology \& Biotechnology. 2001; 26(6):350-355.

49. Predicala B, Nemati M, Stade S, Lague C. Control of $\mathrm{H}_{2} \mathrm{~S}$ emission from swine manure using Na-nitrite and Na-molybdate. Journal of Hazardous Materials. 2008; 154(1-3):300-309.

50. Tanaka S, Lee YH. Control of sulfate reduction by molybdate in anaerobic digestion. Water Science and Technology. 1997; 36:143-150.

51. Jiang G, Gutierrez O, Raj Sharma K, Yuan Z. Effects of nitrite concentration and exposure time on sulfide and methane production in sewer systems. Water research. 2010; 44:4241-4251.

52. Mohanakrishnan J, Gutierrez O, Meyer RL, Yuan Z. Nitrite effectively inhibits sulfide and methane production in a laboratory scale sewer reactor. Water Research. 2008; 42(14):3961-3971.

53. Zhang L, Mendoza L, Marzorati M, Verstraete W. Inhibition of sulfide generation by dosing formaldehyde and its derivatives in sewage under anaerobic conditions. Water Sci Technol. 2008; 57(6):915-9.

54. Greene EA, Brunelle V, Jenneman GE, Voordouw G. Synergistic inhibition of microbial sulfide production by combinations of the metabolic inhibitor nitrite and biocides. Appl Environ Microbiol. 2006; 72:7897-7901.

55. Coates JD, Chisholm JL, Knapp RM, Mcinerney MJ, Menzie DE, Bhupathiraju VK. Microbially enhanced oil recovery field pilot, Payne County, Oklahoma. Microbial enhancement of oil recovery - recent advances. Premuzic ET, Woodhead A, editors. New York: Elsevier; 1992. p. 197-205.

56. Hubert C, Nemati M, Jenneman G, Voordouw G. Containment of biogenic sulfide production in continuous up-flow packed-bed bioreactors with nitrate or nitrite. Biotechnol Prog. 2003; 19:338345.

57. Arensdorf JJ, Miner K, Ertmoed R, Clay WK, Stadnicki P, Voordouw G. Mitigation of reservoir souring by nitrate in a produced-water reinjection system in Alberta. Proceedings of the SPE International Symposium on Oilfield Chemistry, The Woodlands, TX: Society of Petroleum Engineers. 2009

58. Gieg L, Jack T, Foght J. Biological souring and mitigation in oil reservoirs. Appl Microbiol Biotechnol. 2011; 92:263-282.

59. Hubert C, Voordouw G. Oil field souring control by nitrate-reducing Sulfurospirillum spp. that outcompete sulfate-reducing bacteria for organic electron donors. Appl Environ Microbiol. 2007; 73:2644-2652.

60. Gevertz D, Telang AJ, Voordouw G, Jenneman GE. Isolation and characterization of strains CVO and FWKO B, two novel nitrate-reducing, sulfide-oxidizing bacteria isolated from oil field brine. Appl Environ Microbiol. 2000; 66:24912501.

61. Engelbrektson A, Hubbard C, Tom L, Boussina A, Jin YT, Wong $\mathrm{H}$, et al. Inhibition of microbial sulfate reduction in a flow-through column system by (per)chlorate treatment. Front Microbiol. 2014; 5:315.

62. Gregoire P, Engelbrektson A, Hubbard CG, Metlagel Z, Csencsits R, Auer M, et al. Control of sulfidogenesis through bio-oxidation of H2S coupled to (per)chlorate reduction. Environ Microbiol Rep. 2014; 6:558-564.

63. Carlson HK, Kuehl JV, Hazra AB, Justice NB, Stoeva MK, Sczesnak A, et al. Mechanisms of direct inhibition of the respiratory sulfate-reduction pathway by (per)chlorate and nitrate. ISME J. 2015; 9:1295-1305.

64. Youngblut MD, Wang O, Barnum TP, Coates JD. (Per)chlorate in biology on earth and beyond. Annual Rev Microbiol. 2016; 70:435-457.

65. Engelbrektson A, Briseno V, Liu Y, Figueroa I, Yee M, Shao GL, Carlson H, Coates JD. Mitigating sulfidogenesis with simultaneous perchlorate and nitrate treatments. Frontiers in Microbiology. 2018; 9:2305.

66. Mehta-Kolte MG, Loutey D, Wang O, Youngblut MD, Hubbard CG, Wetmore KM, et al. Mechanism of $\mathrm{H} 2 \mathrm{~S}$ oxidation by the dissimilatory perchlorate-reducing microorganism Azospira suillum PS. mBio, 2017; 8:e02023-16. 
67. Varaa M. Agents that increase the permeability of the outer membrane. Microbiol Rev. 1992; 56:395-411.

68. Raad I, Sherertz R. Chelators in combination with biocides: treatment of microbially induced biofilm and corrosion. US Patent 6267979. 2001.

69. Raad I, Chatzinikolaou I, Chaiban G, Hanna H, Hachem R, Dvorak T, Cook G, Costerton W. In vitro and ex vivo activities of minocycline and EDTA against microorganisms embed- ded in biofilm on catheter surfaces. Antimicrob Agents. 2003; 47(11):3580-3585.

70. Wen J, Zhao K, Gu T, Raad I. Chelators enhanced biocide inhibition of planktonic sulfate-reducing bacterial growth. World J Microbiol Biotechnol. 2010; 26(6):1053-1057.

71. Wen J, Zhao K, Gu T, Raad I. A green biocide enhancer for the treatment of sulfate-reducing bacteria (SRB) biofilms on carbon steel surfaces using glutaraldehyde. International Biodeterioration \& Biodegradation. 2009; 63(8):1102-1106.

72. Wen J, Xu D, Gu T, Raad I. A green triple biocide cocktail consisting of a biocide, EDDS and methanol for the mitigation of planktonic and sessile sulfate-reducing bacteria. World J Microbiol Biotechnol. 2012; 28:431-435.

73. Li Y, Jia R, Al-Mahamedh HH, Xu D, Gu T. Enhanced biocide mitigation of field biofilm consortia by a mixture of D-amino acids. Front Microbiol. 2016; 7:896-909.

74. Lam H, Oh DC, Cava F, Takacs CN, Clardy J, de Pedro MA, Waldor MK D-Amino acids govern stationary phase cell wall remodeling in bacteria. Science. 2009; 325(5947):1552-1555.

75. Leiman SA, May JM, Lebar MD, Kahne D, Kolter R, Losick R. D-Amino acids indirectly inhibit biofilm formation in Bacillus subtilis by interfering with protein synthesis. J Bacteriol. 2013; 195(23):5391-5395.

76. Xu D, Jia R, Li Y, Gu T. Advances in the treatment of problematic industrial biofilms. World J Microbiol Biotechnol. 2017; 33:97.

77. Goldman G, Starosvetsky J, Armon R. Inhibition of biofilm formation on UF membrane by use of specific bacteriophages. J Membr Sci. 2009; 342(1-2):145-152.
78. Eydal HS, Jägevall S, Hermansson M, Pedersen K. Bacteiophage lytic to Desulfovibrio aespoeensis isolated from deep groundwater. ISME J. 2009; 3(10):1139-1147.

79. Summer EJ, Liu M, Summer NS, Gill JJ, Janes C, Young R. Phage of sulfate reducing bacteria isolated from high saline envionment. Corrosion/2011 Paper No. 11222, NACE International, Houston. 2011.

80. Vijayakumar S, Saravanan V. Biosurfactants Types, sources and applications. Res J Microbiol. 2015; 10:181-192.

81. Santos DK, Rufino RD, Luna JM, Santos VA, Sarubbo LA. Biosurfactants: Multifunctional biomolecules of the $21^{\text {st }}$ Century. Int J Mol Sci. 2016; 17:401.

82. Płaza G, Achal V. Biosurfactants: Eco-Friendly and innovative biocides against biocorrosion. Molecular Sciences. Int J Mol Sci. 2020; 21(6):2152 .

83. Zuo R, Ornek D, Syrett BC, Green RM, Hsu CH, Mansfeld FB, Wood TK. Inhibiting mild steel corrosion from sulfate-reducing bacteria using antimicrobial-producing biofilms in Three-MileIsland process water. Appl Microbiol Biotechnol. 2004; 64(2):275-283.

84. Purwasena IA, Astuti DI, Fauziyyah NA, Putri DAS, Sugai Y. Inhibition of microbial influenced corrosion on carbon steel ST37 using biosurfactant produced by Bacillus sp. Mater Res Express. 2019; 6(11):115405.

85. Parthipan P, Sabarinathan D, Angaiah S, Rajasekar A. Glycolipid biosurfactant as an ecofriendlly microbial inhibitor for the corrosion of carbon steel in vulnerable corrosive bacterial strains. J Mol Lipids. 2018; 261:473-479.

86. Dagbert C, Meylheuc T, Bellon-Fontaine MN. Corrosion behavior of AISI 304 stainless steel in presence of biosurfactant produced by $\mathrm{PSeu}$ domonas fluorescens. Electrochem Acta. 2006; 51:5221-5227.

87. Astuti DI, Purwasena IA, Putri FZ. Potential of biosufactant as an alternative biocide to control biofilm associated biocorrosion. J Environ Sci Technol. 2018; 11:104-111.

88. Parsek MR, Greenberg E. Sociomicrobiology: the connections between quorum sensing and 
biofilms. Trends Microbiol. 2005; 13(1):27-33.

89. Papenfort K, Bassler BL. Quorum sensing signal-response systems in Gram-negative bacteria. Nat Rev Microbiol. 2016; 14(9):576.

90. Fetzner S. Quorum quenching enzymes. J Biotechnol. 2015; 201:2-14. Epub 2014/09/16.

91. Kawaguchi T, Chen YP, Norman RS, Decho AW. Rapid screening of quorum-sensing signal $\mathrm{N}$-acyl homoserine lactones by an in vitro cell-free assay. Appl Environ Microbiol. 2008; 74:3667-3671.

92. Decho AW, Visscher PT, Ferry J, Kawaguchi T, He LJ, Przekop KM, Norman RS, Reid RP. Autoinducers extracted from microbial mats reveal a surprising diversity of $\mathrm{N}$-acylhomoserine lactones (ahls) and abundance changes that may relate to diel $\mathrm{pH}$. Environ Microbiol. 2009; 11:409-420.

93. Lee S, Park SK, Kwon H, Lee SH, Lee K, $\mathrm{Nah} \mathrm{CH}$, et al. Crossing the border between laboratory and field: Bacterial quorum quenching for anti-biofouling strategy in an MBR. Environ Sci Technol. 2016; 50:1788-1795.

94. Guendouze A, Plener L, Bzdrenga J, Jacquet P, Remy B, Elias M, et al. Effect of quorum quenching lactonase in clinical isolates of Pseudomonas aeruginosa and comparison with quorum sensing inhibitors. Front Microbiol. 2017; 8:227. Epub 2017/03/07.

95. Bergonzi C, Schwab M, Naik T, Daude D, Chabriere E, Elias M. Structural and biochemical characterization of $\mathrm{AaL}$, a quorum quenching lactonase with unusual kinetic properties. Sci Rep. 2018; 8(1):11262. Epub 2018/07/28.

96. Lade H, Paul D, Kweon JH. N-acyl homoserine lactone-mediated quorum sensing with special reference to use of quorum quenching bacteria in membrane biofouling control. Biomed Res Int. 2014; 2014:162584.

97. Huang S, Bergonzi C, Schwab M, Elias M, Hicks RE. Evaluation of biological and enzymatic quorum quencher coating additives to reduce biocorrosion of steel. PLOS ONE. 2019; 16(6): e0253354.
98. Marzorati S, Verotta L, Trasatti SP. Green corrosion inhibitors from natural sources and biomass wastes received. Molecules. 2019; 24(1):48.

99. Zain WSM, Salleh NIH, Abdullah A. Natural biocides for mitigation of sulphate reducing bacteria. Int J Corros. 2018; 3567569:1-7.

100. Lavania M, Sarma PM, Mandal AK, Cheema S, Lai B. Efficacy of natural biocide on control of microbial induced corrosion in oil pipelines mediated by Desulfovibrio vulgaris and Desulfovibrio gigas. Journal of Environmental Sciences. 2011; 23(8):1394-1402.

101. Karonen M, Hämäläinen M, Nieminen R, et al. Phenolic extractives from the bark of Pinus sylvestris $\mathrm{L}$. and their effects on inflammatory mediators nitric oxide and prostaglandin E. Journal of Agricultural and Food Chemistry. 2004; 52(25):7532-7540.

102. Chelossi E, Faimali M, Comparative assessment of antimicrobial efficacy of new potential biocides for treatment of cooling and ballast waters. Science of the Total Environment. 2006; 356(13):1-10.

103. Farjana A, Zerin N, Kabir MS. Antimicrobial activity of medicinal plant leaf extracts against pathogenic bacteria. Asian Pacific Journal of Tropical Disease. 2014; 4(2):S920-S923.

104. Grassino AN, Halambek J, Djakovic' S, Rimac Brnc 'ic' S, Dent M, Grabaric' Z. Utilization of tomato peel waste from canning factory as a potential source for pectin production and application as tin corrosion inhibitor. Food Hydrocoll. 2016; 52:265-274.

105. Fiori-Bimbi MV, Alvarez PE, Vaca H, Gervasi CA. Corrosion inhibition of mild steel in HCL solution by pectin. Corros Sci. 2015; 92:192199.

106. Odewunmi NA, Umoren SA, Gasem ZM. Watermelon waste products as green corrosion inhibitors for mild steel in $\mathrm{HCl}$ solution. J Environ Chem Eng. 2015; 3:286-296.

107. Ismail M, Abdulrahman AS, Hussain MS. Solid waste as environmental benign corrosion inhibitors in acidic medium. Int J Eng Sci. 2011; 3:1742-1748. 
108. Rexin Thusnavis G, Vinod Kumar KP. Green corrosion inhibitor for steel in acid medium. Application No. 6278/CHE/2014 A. 2014.
109. Ponciano Gomes JA, Cardoso Rocha J, D’Elia E. Use of fruit skin extracts as corrosion inhibitors and process for their producing. US Patent US8926867B2. 2015.

Received 28.09.2021 